\title{
POTENSI SUMBERDAYA ALAM PASIR BESI PANTAI ARAKAN KABUPATEN MINAHASA SELATAN
}

\author{
Adey Tanauma ${ }^{1)}$ dan Ferdy ${ }^{1)}$ \\ ${ }^{1)}$ Program Studi Fisika FMIPA Universitas Sam Ratulangi, Manado 95115
}

\begin{abstract}
ABSTRAK
Pasir besi merupakan salah satu sumberdaya alam di Sulawesi Utara yang belum dimanfaatkan secara optimal. Salah satu lokasi yang cukup potensial untuk mendapatkan endapan pasir besi ini adalah pesisir pantai Arakan. Penelitian ini bertujuan untuk menentukan sifat-sifat magnetik endapan pasir besi yang terdapat di pesisir Pantai Arakan kabupaten Minahasa Selatan Provinsi Sulawesi Utara. Suseptibilitas magnetik dan magnetisasi saturasi sampel pasir besi Arakan mengindikasikan bahwa kandungan mineral magnetik yang dominan adalah magnetite. Ukuran bulir dari mineral magnetik terutama magnetite didominasi oleh bulir-bulir magnetik berukuran besar atau bulir magnetik dengan domain magnetik antara pseudosingle domain dan multi domain. Tingginya kandungan mineral magnetik berdasarkan nilai karakterisasinya, terutama nilai suseptibilitas magnetik memberikan peluang untuk pemanfaatan lebih lanjut dari sumberdaya alam ini.
\end{abstract}

Kata kunci: histeresis magnetik, pasir besi, suseptibilitas

\section{THE POTENTIAL OF NATURAL RESOURCES OF IRON SAND IN ARAKAN COASTAL SUBPROVINCE OF SOUTH MINAHASA}

\begin{abstract}
Iron sand represent one of the natural resources in North Sulawesi which not yet been exploited in optimally. One of the location which quite potential to get this iron sand sediment is coastal area of Arakan. This research aim to determine the nature of magnetic of iron sand sediment which there are in coastal area of Arakan, Sub-province of South Minahasa, Province of North Sulawesi. Magnetic suseptibility and saturation magnetization of iron sand sampel of Arakan indicated that dominant magnetic mineral is magnetite. Seed size measure of magnetic mineral especially magnetite predominated by big sized magnetic seeds or magnetic seed with magnetic domain between domain pseudosingle and multi domain. The height content of magnetic mineral based on characteristic value, especially magnetic suseptibility give the opportunity for furthermore exploiting of this natural resources.
\end{abstract}

Keywords : magnetic hysteresis, iron sand, suseptibility

\section{PENDAHULUAN}

Salah satu lokasi yang cukup potensial untuk mendapatkan endapan pasir besi ini adalah pesisir Pantai Arakan di Kabupaten Minahasa Selatan Propinsi Sulawesi Utara. Penampakannya yang banyak di sepanjang pantai memberi kemudahan bahan ini untuk ditambang dan diolah menjadi bahan yang bernilai lebih tinggi.

Bahan alam pasir besi kaya akan mineral yang mengandung besi, mineral yang diperoleh dari sumber daya alam ini dapat dijadikan bahan pembuatan besi baja dan sangat potensial untuk diolah menjadi bahan industri lain yang didasarkan pada sifat-sifat kemagnetannya (Yulianto dkk, 2002), antara lain tinta kering (toner) pada mesin photo copy dan printer laser yang terbuat dari magnetite, sementara maghemite dapat digunakan sebagai bahan utama untuk pita kaset.

Berdasarkan hal di atas, maka pengetahuan tentang jenis mineral magnetik dominan yang dikandung oleh suatu endapan pasir besi menjadi penting untuk memperoleh gambaran nilai ekonomis dari sumber daya 
alam tersebut. Oleh karena itu pada penelitian ini akan dikaji sifat-sifat magnetik dari endapan pasir besi yang berasal dari daerah Arakan wilayah Kabupaten Minahasa Selatan Propinsi Sulawesi Utara dengan menggunakan prosedur standar metode kemagnetan batuan (Rock Magnetism).

Penelitian ini bertujuan untuk menentukan sifat-sifat magnetik dari endapan pasir besi yang terdapat di pesisir Pantai Arakan kabupaten Minahasa Selatan propinsi Sulawesi Utara.

\section{METODE PENELITIAN}

Sampel pasir besi diambil pada lima lokasi pesisir Pantai Arakan Kabupaten Minahasa Selatan, Sulawesi Utara. Setiap sampel diambil pada kedalaman $5 \mathrm{~cm}$ dari permukaan endapan pasir dan setiap lokasi berjarak sekitar $100 \mathrm{~m}$ hingga $200 \mathrm{~m}$ dengan lokasi berikutnya. Pengukuran suseptibilitas magnetiknya menggunakan Bartington Magnetic Susceptibility Meter dengan sensor MS2B.

Pengukuran kurva histeresis / hysteresis loop pada salah satu sampel terpilih untuk memperoleh parameterparameter : Magnetisasi Saturasi $\left(\mathrm{M}_{\mathrm{s}}\right)$, Magnetisasi Remanen Saturasi $\left(\mathrm{M}_{\mathrm{rs}}\right)$, Gaya Koersif $\left(\mathrm{B}_{\mathrm{c}}\right)$, dan Gaya Koersif Remanen $\left(\mathrm{B}_{\mathrm{cr}}\right)$. Penelitian ini dilaksanakan pada tahun 2011, di Desa Arakan klabupaten Minahasa Swelatan Provinsi Sulawesi Utara.

Tabel 1. Suseptibilitas magnetik sampel pasir di daerah Arakan

\begin{tabular}{|c|c|c|c|c|c|c|}
\hline \multirow{2}{*}{ No. } & \multirow{2}{*}{ Kode } & \multicolumn{2}{|c|}{ Sebelum ekstraksi } & \multicolumn{3}{|c|}{ Setelah ekstraksi } \\
\cline { 3 - 7 } & & $\begin{array}{c}\chi_{\text {LF }} \\
\left(\mathbf{1 0}^{-6} \mathbf{m}^{\mathbf{3}} / \mathbf{k g}\right)\end{array}$ & Std & $\begin{array}{c}\chi_{\text {LF }} \\
\left(\mathbf{1 0}^{-4} \mathbf{m}^{\mathbf{3}} / \mathbf{k g}\right)\end{array}$ & $\begin{array}{c}\chi_{\text {HF }} \\
\left(\mathbf{1 0}^{-4} \mathbf{m}^{\mathbf{3}} / \mathbf{k g}\right)\end{array}$ & $\chi_{\text {FD }}(\mathbf{\%})$ \\
\hline 1. & ARK1 & 138.45 & 0.18 & 455.77 & 448.26 & 1.65 \\
\hline 2. & ARK2 & 76.38 & 0.35 & 384.03 & 379.72 & 1.12 \\
\hline 3. & ARK3 & 102.04 & 0.32 & 402.55 & 398.64 & 0.97 \\
\hline 4. & ARK4 & 90.98 & 0.17 & 392.72 & 386.73 & 1.53 \\
\hline 5. & ARK5 & 67.95 & 0.05 & 380.62 & 375.24 & 1.41 \\
\hline
\end{tabular}

\section{HASIL DAN PEMBAHASAN}

\section{Suseptibilitas magnetik}

Tabel 1 menunjukkan hasil pengukuran suseptibilitas magnetik pada lima sampel yang diambil pada lokasi berbeda di pesisir pantai Arakan.

Untuk sampel yang belum diekstraksi nilai suseptibilitas magnetik pada frekwensi rendah $(470 \mathrm{~Hz})$ bervariasi antara $69.75 \times 10^{-6}$ $\mathrm{m}^{3} \mathrm{~kg}^{-1}$ sampai $138.45 \times 10^{-6} \mathrm{~m}^{3} \mathrm{~kg}^{-1}$. Sementara suseptibilitas magnetik pada frekuensi rendah untuk sampel yang sama namun telah diekstraksi berkisar antara $380.62 \times 10^{-6} \mathrm{~m}^{3} \mathrm{~kg}^{-1}$ sampai dengan $448.26 \times 10^{-6} \mathrm{~m}^{3} \mathrm{~kg}^{-1}$. Berdasarkan Dearing (1999), maka kisaran suseptibilitas magnetik dari sampel-sampel tersebut mengindikasikan bahwa mineral magnetik yang dominan adalah magnetite $\left(\mathrm{Fe}_{3} \mathrm{O}_{4}\right)$ dengan ukuran bulir antara $1-250 \mu \mathrm{m}$.

Kuatnya dominasi ukuran bulir-bulir magnetik yang cukup besar terlihat juga pada hasil perhitungan nilai suseptibilitas magnetik bergantung frekuensi $\left(\chi_{\mathrm{FD}}\right)$ yang cukup kecil yaitu berkisar antara $0.97 \%-1.65 \%$. Seperti diketahui bahwa nilai $\chi_{\mathrm{FD}}$ mengindikasikan konsentrasi relatif mineral magnetik yang memiliki ukuran bulir lebih kecil dari $30 \mathrm{~nm}$ yang biasa dikenal dengan nama bulir superparamagnetik (SP). Makin tinggi nilai $\chi_{\mathrm{FD}}$ makin besar pula konsentrasi bulir SP dalam sampel (Gambar 1).

Gambar 2 menunjukkan plot nilai suseptibilitas magnetik bergantung frekuensi terhadap suseptibilitas magnetik pada frekuensi rendah. Pola yang cenderung mengumpul untuk semua sampel, kecuali ARK1, dapat menjadi karakteristik khusus 
dari sampel-sampel pasir besi yang berasal dari daerah Arakan dibandingkan dengan yang berasal dari daerah lain

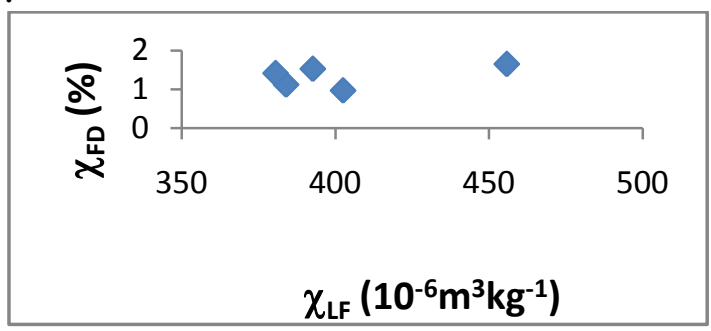

Gambar 1. Plot $\chi_{\mathrm{FD}}$ terhadap $\chi_{\mathrm{LF}}$

\section{Suseptibilitas magnetik bergantung suhu}

Berdasarkan hasil pengukuran suseptibilitas yang bergantung suhu, diukur mulai pada suhu $-193{ }^{\circ} \mathrm{C}$ sampai pada suhu kamar $23{ }^{\circ} \mathrm{C}$ (Gambar 2). Untuk kedua sampel yang diukur yaitu ARK1 dan ARK2 memiliki pola suseptibilitas magnetik yang cenderung sama. Kedua sampel tidak mengalami peningkatan suseptibilitas magnetik pada suhu $-193{ }^{\circ} \mathrm{C}$ sampai $-120{ }^{\circ} \mathrm{C}$ tetapi kemudian meningkat secara drastis pada suhu sekitar $-120{ }^{\circ} \mathrm{C}$ sampai $-50{ }^{\circ} \mathrm{C}$, dan cenderung tetap pada suhu sekitar $-50{ }^{\circ} \mathrm{C}$ sampai $-12{ }^{\circ} \mathrm{C}$, kemudian akhirnya meningkat cukup signifikan pada suhu sekitar $-10{ }^{\circ} \mathrm{C}$.

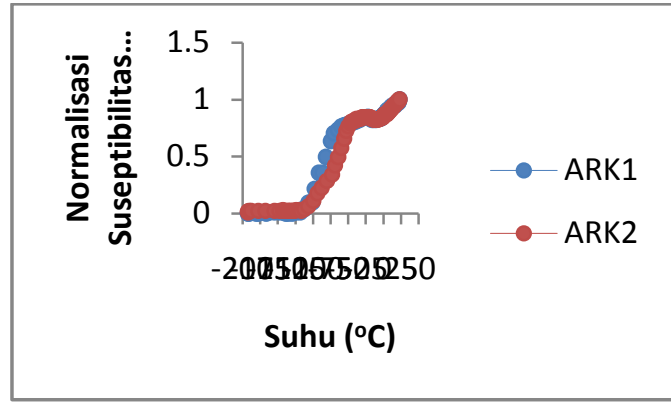

Gambar 2. Suseptibilitas magnetik sebagai fungsi dari suhu

Perubahan suseptibilitas magnetik yang cukup signifikan pada suhu $-120^{\circ} \mathrm{C}$ dan $-10{ }^{\circ} \mathrm{C}$ menunjukkan terjadinya transisi fasa pada mineral magnetik yang diukur. Menurut Halgedahl \& Jarrard (1995), transisi fasa pada suhu sekitar $-163{ }^{\circ} \mathrm{C}$ sampai dengan $153{ }^{\circ} \mathrm{C}$ disebut sebagai transisi Verwey yang menunjukkan dominasi mineral ferimagnetik magnetite $\left(\mathrm{Fe}_{3} \mathrm{O}_{4}\right)$ pada sampel. Tarnawski $d k k$ (2004) juga pernah menuliskan bahwa transisi Verwey dapat terjadi disekitar -148 ${ }^{\circ} \mathrm{C}$. Namun transisi fasa dari sampel pasir besi Arakan yang terjadi pada suhu $-120{ }^{\circ} \mathrm{C}$ mengindikasikan kehadiran mineral magnetik yang lain selain magnetite. Transisi fasa kedua yang terjadi pada suhu sekitar $-10{ }^{\circ} \mathrm{C}$ menunjukkan transisi Morin (Bowles $d k k$, 2010) yang mengindikasikan adanya mineral magnetik seperti hematite $\left(\gamma-\mathrm{Fe}_{2} \mathrm{O}_{3}\right)$. Dapat dikatakan bahwa mineral magnetik yang dominan terdapat pada sampel pasir besi dari Arakan adalah magnetite dan hematite.

\subsection{Parameter histeresis magnetik}

Gambar 3 menunjukkan kurva histeresis magnetik terkoreksi massa sebagai hasil pengukuran yang dilakukan pada sampel ARK2. Dari kurva tersebut diperoleh nilai saturasi magnetik $4.63 \mathrm{Am}^{2} / \mathrm{kg}$, nilai magnetisasi remanen $1.10 \quad \mathrm{Am}^{2} / \mathrm{kg}$, sedangkan medan koersifitasnya berkisar 5.6 $\mathrm{mT}$. Berdasarkan nilai saturasi magnetiknya maka terindikasi bahwa mineral magnetik dalam sampel kemungkinan didominasi oleh magnetite $\left(\mathrm{Fe}_{3} \mathrm{O}_{4}\right)$ atau maghemite $\left(\gamma-\mathrm{Fe}_{2} \mathrm{O}_{3}\right)$, sedangkan kecilnya nilai koersifitas atau kurusnya kurva hysteresis mengindikasikan bulir-bulir berukuran besar dengan domain magnetik antara pseudosingle domain dan multi domain. Perbandingan antara nilai magnetisasi remanen dengan magnetisasi saturasi yang bernilai 0.24 menunjukkan bahwa bulir-bulir magnetik terutama magnetite yang ada pada sampel pasir besi Arakan adalah pseudosingle domain (Evans and Heller, 2003).

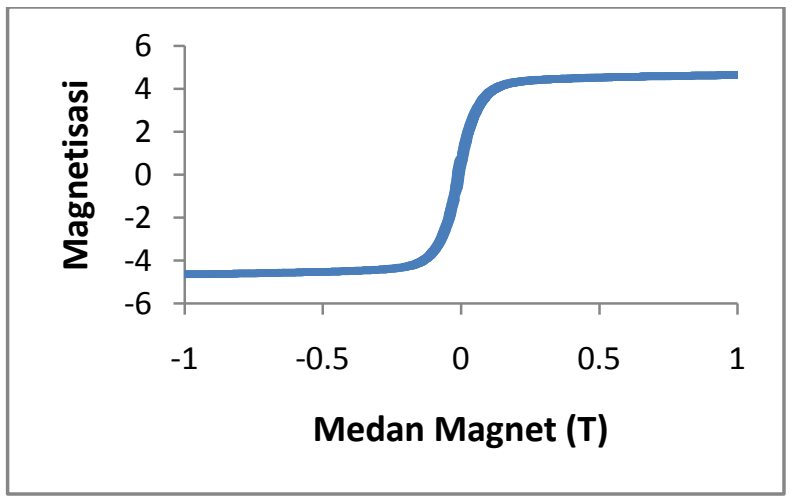

Gambar 3. Kurva histeresis sampel ARK2. 


\section{KESIMPULAN}

Hasil pengukuran dan analisis beberapa parameter magnetik pada sampel pasir besi yang berasal dari wilayah Arakan di Kabupaten Minahasa Selatan Sulawesi Utara menunjukkan bahwa:

1. Karakteristik magnetik antara lain suseptibilitas magnetiknya berkisar antara $69.75 \times 10^{-6} \mathrm{~m}^{3} \mathrm{~kg}^{-1}$ sampai $138.45 \times 10^{-6}$ $\mathrm{m}^{3} \mathrm{~kg}^{-1}$ dan magnetisasi saturasinya 4.63 $\mathrm{Am}^{2} / \mathrm{kg}$.

2. Tingginya nilai suseptibilitas magnetik dan magnetisasi saturasi dari sampel pasir besi Arakan mengindikasikan kandungan mineral magnetik yang dominan adalah magnetite. Namun demikian kehadiran mineral magnetik lain seperti hematite juga telah ditunjukkan melalui hasil pengukuran suseptibilitas magnetik sebagai fungsi suhu.

3. Ukuran bulir dari mineral magnetik terutama magnetite didominasi oleh bulirbulir magnetik berukuran besar atau bulir magnetik dengan domain magnetik antara pseudosingle domain dan multi domain.

4. Tingginya kandungan mineral magnetik berdasarkan nilai karakterisasinya terutama nilai suseptibilitas magnetik memberikan peluang untuk pemanfaatan lebih lanjut dari sumber daya alam ini.

\section{DAFTAR PUSTAKA}

Bowles, J., Jackson, M., Banerjee, S. 2010. Interpretation of Low-Temperature Data Part II: The Hematite Morin Transition. Quarterly Vol. 20. No.1.
Dearing, J.A. $1999 . \quad$ Environmental Magnetic Susceptibility Using the Bartington MS2 System. British Library Cataloging in Publication Data.

Dunlop, D.J., O. Ozdemir. 1997. Rock Magnetism: Fundamental and Frontiers. Cambridge University Press.

Evans, M.E., and F. Heller. 2003. Environmental Magnetism. Academic Press.

Gubbins, D., E. Herrero-Bervera. 2007. Encyclopedia of Geomagnetism and Paleomagnetism. Springer Verlag.

Halgedahl, S.L., R.D. Jarrard. 1995. LowTemperature Behavior of SingleDomain Through Multidomain Magnetite. Earth and Planetary Science Letters.

Tanauma, A. dan Ferdy. 2011. Kajian Sifatsifat Magnetik Pasir Besi Pantai Arakan Kapupaten Minahasa Selatan Provinsi Sulawesi Utara. Laporan Penelitian. Lembaga Penelitian Unsrat. Manado.

Tarnawski, Z., A. Wiechec, M. Madej, D. Nowak, D. Owoc, G. Krol, L. Kakol, Kolwics-Chodak, A. Kozlowski, T. Dawid. 2004. Studies of The Verwey Transition in Magnetite. Acta Physica Polonica A Vol. 106 No. 5.

Yulianto, A., S. Bijaksana, W. Loeksmanto. 2002. Karakterisasi Magnetik dari Pasir Besi Cilacap. Jurnal Fisika, HFI, Suplemen Prosiding Vol. A5 No. 0527. 